\title{
Participation Right Fulfillment in Early Childhood Education through Educative Game Tools
}

\author{
Senowarsito, Siti Musarokah \\ English Education Department, Universitas PGRI Semarang, Kampus 4 Universitas PGRI Semarang, \\ Jl. Gajah Raya No. 30B Semarang, Indonesia
}

\begin{tabular}{l} 
Article Info \\
\hline Article history: \\
Received Oct 16, 2017 \\
Revised Jun 13, 2018 \\
Accepted Jun 30, 2018 \\
\hline
\end{tabular}

Keywords:

Child friendly learning

Early childhood education

Participation right fulfillment

\begin{abstract}
The research aims at describing the implementation of participation rights in early childhood education through educative game tools (Alat Permainan Edukatif: $A P E$ ) and finding out the problems encountered by the teachers in implementing participation rights through $A P E$. The research type is qualitative research. The subjects of the research were four teachers of early childhood education in Semarang Municipality including play group and kindergarten school which were selected by using purposive sampling. The data were collected by field observation and depth-interview and analyzed in the form of a descriptive qualitative analysis. The results show that some APEs implemented in early childhood education were potentially able to enhance participation rights, but the teachers were not aware on this aspect. They tended to focus on the academic outputs and on fulfilling joyful learning. The main factor was the teachers' knowledge on the importance of $A P E$ for comprehending the participation rights of the child in learning process, including the limited number of $A P E$ s created and the flexibility of the $A P E$ s available. As participation rights are essential in learner-centered approach, $A P E$ as an educational game tool should be created and manipulated to accommodate the rights, including protection and provision rights.
\end{abstract}

Copyright $(2018$ Institute of Advanced Engineering and Science. All rights reserved.

\section{Corresponding Author:}

Siti Musarokah,

Program Studi Pendidikan Bahasa Inggris,

Universitas PGRI Semarang,

Kampus 4 Universitas PGRI Semarang, Jl. Gajah Raya No. 30B Semarang, Indonesia.

Email: sitimusarokah@upgris.ac.id

\section{INTRODUCTION}

The purpose of early childhood education in Indonesia context (the 2013 curriculum of PAUD) is to develop the children's complementary competence on attitudes, knowledge, and skills, which are relating to some aspects such as spiritual and moral values, physico-motoric, cognitive, language, social-emotional, and arts $[1,2]$. The main concern is in fulfilling all the children's needs to enhance the maximum capacities to survive in the future life. In child rights perspectives, early childhood education should accommodate 4 principles of child rights: non-discrimination, best interests of the child, right to life and maximum survival and development, and respect for the views of the child. Those rights are simplified into protection rights, provision rights, and participation rights [3-7]. Participation rights concern with how a learning process in early childhood education implements child-centred approach that gives a space for children to express their views and opinions to promote child participation [8]. In this case, in leaning process, the role of the teacher and the existing learning media and educative tools are prominence in facilitating learners to gain the expected learning outcomes. The teacher as facilitator should be able to create a learning process allowing and supporting learners to enhance their participation in learning activities. Moreover, the accomplishment of 
the learning process should be supported by the media or educative game tools that accommodate the learner's need to have space on expressing their views and ideas.

Some researches on educative game tools (In Indonesia, it is well-known as Alat Permainan Edukatif, $A P E$ ) in early childhood education were conducted in different focuses and perspectives. The first research [9] observed educative game tools used by teachers for teaching the Kindergarten students of Polewali, Bone, Indonesia. It is focused on kinds of APEs implemented by teachers in learning process and found that the APEs implemented by the teachers were still limitation in a number and ranges. The second research [10] concerned on how out-door educative game tool to enhance children's physical motoric aspects. It found that outdoor educative game tools significantly developed children's physical motoric, but the teacher rarely used outdoor educative game tools in learning process. Next research [11] concentrated on the efforts to educate children by using educative game tools. It found that parents have an important role in choosing the educative game tools for their children.

To fulfill the children's need for joyful learning and expected outcomes, the development of educative game tools should be taken into consideration. Research on the development of educative game tools had been done as well [12]. It developed web-based APEs model, and it proved that this model could enhance the creativities and psycho motoric of children. Interactive multimedia-based educative game tool was also developed by Putra [13]. This research revealed that interactive multimedia-based educative game tool could improve the students' ability in reading more than other conventional media, such has books, pictures, posters, or cards.

This present study is significantly different from those previous researches which much concerned on implementation and the development of educative game tools to improve the learner's competences. However, the fulfillment of the rights of the child in the classroom, especially in early childhood education has not become the substantial issue for the researchers. In fact, these rights including provision, protection, and participation [14] should be the fundamental and vital rights for the children. Moreover, whatever the method, technique, or teaching media used, teachers should always fulfill those all children rights to create child friendly learning in early childhood education [15]. The questions can be address to what extent are participation rights implemented in early childhood education through educative game tools and the problems encountered by the teachers in implementing participation rights through the game tools. Therefore, this research aims at describing the fulfillment of participation rights in early childhood education through educative game tools (APE) and at finding out the problems encountered by the teachers in implementing participation right through APE.

\section{RESEARCH METHOD}

The research type is qualitative research. It is synthesized that qualitative research is the research done to understand phenomena which are experienced by the research subject, namely behavior, perception, motivation, action, etc [16]. The subjects of the research were four teachers of early childhood education in Semarang including play group (Kelompok Bermain), early childhood education (Pendidikan Anak Usia Dini), kindergarten school (Taman Kanak-Kanak) which were taken by using purposive sampling. The techniques used to collect the data were field-observation equipped with video-recorder and depth-interview. Field observation was done in the learning processes conducted by those four teachers in their school to examine the application of participation rights and the problems encountered by the teachers in implementing participation rights through the APE they used. The results of the depth-interview were used to support the main data. The data were analyzed by reducing the data, displaying the data, and drawing conclusion [17]. In reducing the data, we identified the results of the observation, and we omit some data which were irrelevant with the research objectives. After that, we displayed the data in the table to make the data easy to describe. The last step in analyzing the data is drawing conclusion; it was done based on the research result analysis.

\section{RESULTS AND ANALYSIS}

\subsection{Implementation of Participation Right by Teachers of Early Childhood Education through Educative Game Tools}

To know the implementation of participation right by the teachers of Early Childhood Education through Educative game tools (APEs), we observed the APEs used by the teachers and interviewed them. The observation was conducted for knowing the participation right implemented by the teacher in teaching learning process. The result of observasion shows that some APEs implemented in early childhood education were potentially able to enhance participation rights, but the teachers were not aware on this aspect. They tended to focus on the academic outputs and on fulfilling joyful learning. It was found that three of early childhood educations observed have limited APEs. Even in one schools, the availability of the APEs can be 
counted with fingers, and the other one has sufficient APEs. Thus, it limits the fulfillment of the child's participation rights. However, the availability of game tools in schools should not be the basis for fulfilling the right of child to participate in teaching learning process because teachers can take the advantage of the available game tools to fulfill the child's participation right as widely as possible. It was also found that some APEs are in a dusty condition. This shows that the APEs are rarely used by the teachers in teaching learning process. Moreover, it was found that there are some APEs still wrapped in their wraps. This proves that the APEs available in the early childhood education are not considered important in teaching learning process. In other words, teachers are not aware that APEs can actually enhance the child rights to participate in teaching learning process.

In addition, to support the main data of the research, we gave two main questions to the teachers. The questions are "How is the implementation of Educative Game Tools in teaching learning process?" and "How are the rules of the game made?" The questions in the interview were composed without showing the main topic of the question, Participation Right of the child. It was done based on the consideration that the answers of the teachers would be real. The results of the interview can be shown in the Table 1 .

Table 1. Implementation of Participation Right by the Teacher

\begin{tabular}{|c|c|c|}
\hline Teacher Code & Answers of Question 1 & Answer of Question 2 \\
\hline $\mathrm{T} 1$ & $\begin{array}{l}\text { Teacher implements APE based on the theme of the lesson; } \\
\text { the APEs are implemented individually and groups. If the } \\
\text { APEs can only be played individually, the teacher asks the } \\
\text { students to play alternately. }\end{array}$ & $\begin{array}{l}\text { Teacher often makes the rules herself, but } \\
\text { sometimes the students make them. }\end{array}$ \\
\hline $\mathrm{T} 2$ & $\begin{array}{l}\text { Teacher implements APE based on the theme of the lesson; } \\
\text { APEs are often implemented individually because the number } \\
\text { of the APEs is very limited. }\end{array}$ & $\begin{array}{l}\text { Teacher always makes the rules herself because } \\
\text { she thinks that the students are not able to make } \\
\text { the rules alone. }\end{array}$ \\
\hline $\mathrm{T} 3$ & $\begin{array}{l}\text { Teacher implements APE based on the theme of the lesson; } \\
\text { APEs are implemented individually and groups. If the APEs } \\
\text { can only be played individually, the teacher asks the students } \\
\text { to play alternately. }\end{array}$ & $\begin{array}{l}\text { Teacher always makes the rules herself; Students } \\
\text { are not able to make the rules themselves } \\
\text { because they are too young to make the rules. }\end{array}$ \\
\hline $\mathrm{T} 4$ & $\begin{array}{l}\text { Teacher implements APE based on the theme of the lesson; } \\
\text { APEs are implemented individually, pairs and groups. If the } \\
\text { APEs can only be played individually, the teacher asks the } \\
\text { students to play alternately. }\end{array}$ & $\begin{array}{l}\text { The rules are made by the teacher, but sometimes } \\
\text { the students are given the opportunity to make } \\
\text { the rules of the game together. }\end{array}$ \\
\hline
\end{tabular}

From the Table 1, the teachers' ways in implementing Educative Games Tools are almost same. They tend to use thematic approach in learning process that accommodate and correlate one subject into several subjects or sub-subjects. For example, Teacher 3 implemented carpentry equipment for teaching "profession". In addition, all of the teachers implement Educative Game Tools both individually and in groups, but teacher 4 implementing them not only individually and in groups but also in pairs. Moreover, if the APEs can be played individually, most of the teachers direct the students to play alternately. They think that all students have the same right to play the APEs. However, based on the result of observation, teacher 2 tends to implement APEs individually because the availability of the game tools is limited, so the students play the game tools alternately.

Furthermore, the Table 1 also shows how the rules of the game are made. The interview result of this topic shows that all teachers tend to make the rules of the game tools used in teaching learning process by themselves. They think that early children have not been able to make the rules themselves, and the teachers worry if the students who make the rules the learning process will not run well. However, teacher 1 and teacher 4 sometimes give the students opportunity to make the rules themselves, but they still accompany the students and give guidance to the students to make learning process run smoothly.

Form those results, it can be concluded that participation right which should be given to the children has not been fully implemented by the teachers. Actually, teachers do not need to worry with the students' capability in making the rules in the classroom because early children basically can make a decision. Students should be trained to decide on a few things themselves, so they get used to making their own decisions since childhood, and eventually they become independent when they grow up. By giving trust to children since childhood, it will make students more confident as well. In this case, all the rules which the children make remain under the supervision and guidance of teachers. It is suggested that "teachers should facilitate their students in having many experiences in order that they can construct knowledge through the experiences" [18]. In this case, it is an experience to make decision by themselves. 


\subsection{Problems Encountered by the Teachers of Early Childhood Education in Implementing Participation Right through Educative Game Tools}

Form the result of observation and interview, there are two main problems encountered by the teachers in implementing participation right on early childhood education through the use of educative game tools $(A P E S)$. They are the limited number and varieties of $A P E$ in schools and the teachers' knowledge on the importance of $A P E$ for fulfilling the participation rights of the child in learning process.

The first problem encountered by the teachers is the limited number and varieties of $A P E$ in schools. Teacher 1,2, and 3 encountered the problem of limited number and varieties of APE. From the result of direct observation in their schools and interview, we found that the number of APE is still very limited. We found in one school there were only a few APEs available which were placed in one box only. Teachers tended to use books in teaching learning process. Teacher 3 added that because of the limited number of APEs, sometimes students scramble or fight to use the game tools which they are interested in. As we know, learning in early childhood will be more meaningful when teachers use instructional media that can be touched or held, and direct learning experiences will be more easily accepted by children than just by hearing the explanation from the teachers or seeing something. It is said that "Young learners actively construct meaning from their experiences. They learn through hands-on experiences and through manipulation of objects in the environment" [18]. Because of the limited number and varieties of APE available in schools, the right of the child to participate in using APEs is ignored. It means that children have limited experience in learning. Although the limited number of APE is not the cause of the lack of the fulfillment of participation right of the child, the varieties of APE which can fulfill participation right became the problem of Teacher 4 . Based on the observation, mostly the APEs found in school of Teacher 4 was only for 2 or 3 learning purposes. For example, they were implemented to develop cognitive and motoric skill, cognitive and language skill, or cognitive, motoric and language skill, but other skills, such as social skill was not fulfilled well. Therefore, this made the teacher had difficulties in implementing participation rights in learning process.

The second problem is teachers' knowledge on the importance of APEs for fulfilling the participation right of the child. It was found some APEs in a dusty condition. This shows that the APEs are rarely used by the teachers in teaching learning process. Moreover, we found that there are some APEs are still wrapped in the plastics. When they were asked why the APES were not utilized, they argued that they worried the game tools would be quickly damaged or lost. It seems that all teachers focused on academic and the development of kinesthetic with thematic approach, so some aspects were neglected such as the children rights, especially participation rights. In short, the limitation of instructional media utilization in teaching learning process can be caused by the lack of teachers' knowledge on the importance of APEs for fulfilling the participation right of the child. They are not aware that APEs can help to fulfill the participation right of the child, so they ignore the participation right of the child which should be given to the child.

From those findings, it seems that Educative Game Tools (APEs) to fulfill the participation right of the child has not been fully implemented by the teachers because of two main factors. The limited number and varieties of the APEs in schools and teachers' knowledge on the importance of APEs for fulfilling the participation right of the child become the problems encountered by the teachers of Early Childhood Education in implementing participation right of the child through APEs.

\section{CONCLUSION}

In conclusion, some APEs implemented in early childhood education were potentially able to enhance participation rights, but the teachers were not aware on this aspect. They tended to focus on the academic outputs and on fulfilling joyful learning. The main factor was the teachers' knowledge on the importance of $A P E$ for comprehending the participation rights of the child in learning process, including the limited number of $A P E$ s created and the flexibility of the APEs available. As participation rights are essential in learner-centered approach, $A P E$ as an educational game tool should be created and manipulated to accommodate the rights, including protection and provision rights.

\section{ACKNOWLEDGEMENTS}

We would like to express our appreciation for the financial support of Kemenristek DIKTI and the Rector of Universitas PGRI Semarang for facilitating them in conducting the research. 


\section{REFERENCES}

[1] Peraturan Menteri Pendidikan dan Kebudayaan Republik Indonesia Nomor 146 Tahun 2014 Tentang Kurikulum 2013 Pendidikan Anak Usia Dini

[2] A. Winti, H. Charlotte A., S. Endah, "Trilingual Learning Model Through Traditional Games: An Overview from An Indonesian Kindergarten," International Journal of Early Childhood Education Care, Vol. 5, pp. 50-56, 2016.

[3] Senowarsito, et al., "Child Friendly Teaching Model in English Language Teaching: an Attempt to Promote Provision, Protection, and Participation," Proceeding International TEFL Conference on Current Belief in ELT and Its Implication in English Classrooms, English Education - UNS, Surakarta-Indonesia, May 18, 2013.

[4] Senowarsito, L. Sumardiyani, A. Setyaji, and S. Widodo, "Parents-School-Students-Forum (P2SF) as Intervention Model on Child Friendly Education," Proceeding of the First International Conference on Child - Friendly Education, pp. 275-281, 2016.

[5] D. Nugrahani, Senowarsito, and S. Musarokah, "Local Plants as Alternative Media to Promote Child Friendly Learning: Best Practice in RA Al Hikmah and RA Al Muta'alimin, Semarang Municipality," Proceeding of the First International Conference on Child - Friendly Education, pp. 472-477, 2016.

[6] Senowarsito and Y. K. Werdiningsih, "The Revitalization of Traditional Game Tools in Child-friendly Education Perspectives," Proceeding ICONS, Pengurus Besar PGRI, Yoyakarta, 2017

[7] Muhdi, Senowarsito, and U. Hidayati. (2010). The Implementation of Child Friendly Teaching Model (CFTM), Classroom and School Management in CRC Perspectives for SMP Negeri (State Secondary School) Tempuran I, Magelang, Central Java, Change Projects from The International Training Programme, Child Rights, Classroom and School Management, Batch 13, Lund University Commissioned Education, Lund, Sweden.

[8] Senowarsito, et. al. (2013). Provisi, Proteksi dan Partisipasi dalam Pembelajaran Bahasa Inggris SMP di Sekolah Model Ramah Anak di Kabupaten Magelang. Semarang: LPPM IKIP PGRI Semarang.

[9] Syamsuardi, "Penggunaan Alat Permainan Edukatif (APE) Di Taman Kanak-Kanak PAUD Polewali Kecamatan Tanete Riattang Barat Kabupaten Bone," Publikasi, Volume II No. 1 Februari-Mei, pp. 59-67, 2012.

[10] I. M. Arif, "Alat Permainan Edukatif Outdoor Yang Digunakan Mengembangkan Motorik Kasar di TK seKecamatan Wonosari Gunungkidul," Jurnal Pendidikan Anak Usia Dini, Edisi 8 Tahun ke-5, pp. 856-863, 2016.

[11] A. Khobir, "Upaya Mendidik Anak Melalui Permainan Edukatif," Forum Tarbiyah, Vol. 7, No. 2, Desember 2009, pp. 195-208, 2009.

[12] S. Wati, M. Syukri, and Wahyudi, "Pengembangan Alat Permainan Edukatif Dalam Pembelajaran Model Webbed Pada Anak Usia 5-6 Tahun," Jurnal Pendidikan dan Pembelajaran, Vol. 3 No. 1, 2014, pp. 1-15, 2014.

[13] F. P. Putra, "Pengembangan Alat Permainan Edukatif (APE) Bahasa Indonesia Berbasis Multimedia Interaktif untuk Pendidikan Anak Usia Dini dalam Meningkatkan Kemampuan Membaca," Tesis, 2015.

[14] Listyaning S. et al. "Child Friendly Teaching Model (CFTM): Model pengajaran ramah anak." Semarang: IKIP PGRI Semarang Press.

[15] S. Musarokah, "3P (Provisi, Proteksi, Dan Partisipasi) dalam Pembelajaran Menggunakan Game di Madrasah Ibtidaiyah: Penerapan dan Tantangannya," Malih Peddas: Majalah Ilmiah Pendidikan Dasar, Vol. 6 No. 2. 2016.

[16] L. J. Moleong, "Metodologi Penelitian Kualitatif,” Bandung: PT Remaja Rosdakarya, 2007.

[17] M. B. Miles and A. M. Huberman, "Qualitative Data Analysis" (2nd edition), Thousand Oaks, CA: Sage Publication, 1994.

[18] Juhana, "Teaching English to Young Learners: Some Points to be Considered," Asian Journal of Education and eLearning, Volume 02 - Issue 01, February 2014, pp. 43-46, 2014. 


\section{BIOGRAPHIES OF AUTHORS}

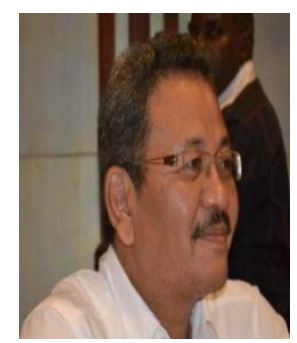

Senowarsito, a doctor of Linguistic-Pragmatics, is a lecturer of English Education Department, and Vice Dean of Student Affairs, Faculty of Language and Arts Education, Universitas PGRI Semarang (UPGRIS). He is also the head of Woman Empowerment and Child Protection Division in the Centre of Population, Woman and Child Protection (PKPPA), LPPM, Universitas PGRI Semarang; the Chairman of the Editorial Board of PKPPA Bulletin; the Chairman of Managing Editor of e-Journal E_DIMAS, LPPM, Universitas PGRI Semarang; and works as instructors on Teacher Training Programs and Profession Education for Teacher at Universitas PGRI Semarang. He is a Change Agent (Batch 13) of ITP on Child Rights, Classroom and School Management, Lund University and SIDA 2010-2012. His researches and projects on Child Rights are Child Friendly Teaching Model in English Language Teaching: an Attempt to Promote Provision, Protection, and Participation (2013); ParentsSchool-Students-Forum (P2SF) as Intervention Model On Child Friendly Education (2015); Local Plants As Alternative Media To Promote Child Friendly Learning: Best Practice In RA Al Hikmah And RA Al Muta'alimin, Semarang Municipality (2015); Traditional Educative Game Tools-based $3 P$ (Provision, Protection and Participation) for Early Childhood Education in Semarang (2016); DAKO3PI as Educative Game Tools for Early Childhood Education in Semarang (2016); and Child-Friendly Educative Game Tools (APE) in 3Ps Perspectives (2017). Working with Muhdi, the Rector of Universitas PGRI Semarang and Umi Hidayati, the principal of SMP Negeri Tempuran I, Magelang, he is developing a child friendly school model and some clusters for State Secondary Schools in Magelang, Central Java.

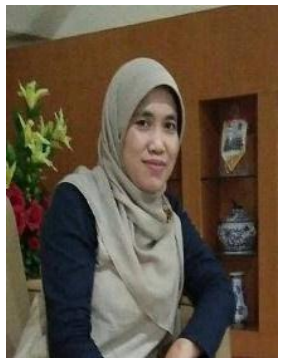

Siti Musarokah is a lecturer of Writing in English Education Department of Universitas PGRI Semarang. She is actively doing the researches after graduating from Post Graduate Program on Applied Linguistics. She concerns on research of writing and child friendly learning. Some of her researches and/or community services on child friendly learning published in journals or proseedings are namely (1) IbM Raudhatul Athfal Al Hikmah Gayamsari dan Raudhatul Athfal Al Muta'alimin Kecamatan Tembalang Sebagai Sekolah Model Ramah Anak (2015), (2) Local Plants as Alternative Media to Promote Child Friendly Learning: Best Practice in RA Al Hikmah and RA Al Muta'alimin, Semarang Municipality (2016), (3) 3P (Provisi, Proteksi, dan Partisipasi) dalam Pembelajaran Menggunakan Game di Madrasah Ibtidaiyah: Penerapan dan Tantangannya (2017), (4) Child-Friendly Educative Game Tools (APE) in 3Ps Perspectives (2017). 